\title{
Pengembangan Bahan Ajar Aktivitas Media Nyata untuk Meningkatkan Hasil Belajar IPA Siswa di Sekolah Dasar
}

\author{
Ani Wahyuni ${ }^{1}$, Anisa Rahman ${ }^{2}$, Cindri Cantika ${ }^{3}$, Eci Puspita ${ }^{4}$, Melina \\ Hasanati $^{5}$, Khorun nisa $\mathrm{Hsb}^{6}$, Muhammad Mahkota Lubis ${ }^{7}$, Siti Nurbaitie ${ }^{8}$ \\ 1,2,3,.,8 Pendidikean Guru Madrasah Ibtidaiyah Universitas Islam Negeri Sumatra Utara \\ e-mail:Pgmi2018aniwahyuni@gmail.com
}

\begin{abstract}
ABSTRAK. The purpose of this study is to improve student learning outcomes using real media tools and using LKPD (Student worksheets). Student LKPD contains energy saving material steps and how to use real media tools, after which the researcher makes a pretest, and protests questions. Student learning achievement is learning outcomes expressed in the form of grades or in the form of scores, after students take lessons, using learning media can improve student learning outcomes, namely real media. Teachers become the main pioneers in developing the potential of students through creative ideas and will create active, critical students.
\end{abstract}

Kata kunci: Achievement, teachers and LKPD

\section{PENDAHULUAN}

Guru sebagai pendidik profesional bertugas untuk mendidik, mengajar, membimbing, mengarahkan, melatih, menilai, dan mengevaluasi peserta didik pada pendidikan anak usia dini pada jalur pendidikan formal. Dalam pelaksanaan tugasnya, guru bertanggung jawab terhadap peserta didik, orang tua, masyarakat, bangsa, negara, dan agama. Guru yang menjalankan tugasnya dengan baik disebut guru yang profesional, yakni guru yang memiliki beberapa keahlian atau kompetensi meliputi pedagogik, kepribadian, sosial, dan profesional yang terjalin satu dengan lainnya. guru menurut Zahara Idris dan Lisma Jamal dalam Idris (2008: 49) adalah orang dewasa yang bertanggung jawab memberikan bimbingan kepada peserta didik dalam hal perkembangan jasmani dan ruhaniah untuk mencapai tingkat kedewasaan, memenuhi tugasnya sebagai makhluk Tuhan, makhluk individu yang mandiri, dan makhluk sosial. Al-Gazali tidak membedakan kata pengajaran dan pendidikan sehingga guru dan pendidik juga tidak dibedakan (Rusn: 63). Hal ini senada dengan pandangan Abi Salih (1410: 10). Ia memandang bahwa sesungguhnya istilah tarbiyyah dan ta'lîm dalam pendidikan Islam sama saja. Pendapatnya demikian karena melihat kenyataan bahwa di dalam al-Qur'an kedua kata itu digunakan untuk mengungkapkan kegiatan pengajaran dan pendidikan yang meliputi semua segi perkembangan manusia. Dengan demikian, guru dan pendidik sama saja. 
Salah satu tolak ukur untuk menilai keberhasilan mengajar adalah menggunakan hasil yang dicapai siswa dalam belajar. Meskipun hingga saat ini alat yang digunakan untuk menilai atau mengukur keberhasilan belajar belum diketahui tingkat keobyektifan, namun keberhasilan belajar siswa yang dicapai siswa berdasarkan penilaian "sebagai mana adanya", member petunjuk bahwa para guru dituntut untuk lebih meningkatkan hasil belajar siswanya.

Perkembangan media sangat pesat, termasuk juga media dalam pembelajaran. Barnes (1979) mengemukakan media pembelajaran akan sangat berperan di masa yang akan datang, tapi seperti apa kemungkinan akan terjadi, mengingat tren, praktik, dan filosofi saat ini. Untuk memahami penggunaan media di masa depan, salah satunya harus memahami lingkup perubahan sosial dan kondisi saat ini. Lawless (1995) Bahwa desain pembelajaran berbasis teknologi dengan cepat menjadi desain yang paling menonjol untuk pembelajaran di kelas. Pendapat serupa mengenai hasil belajar diutarakan oleh Jihad dan Haris (2008) bahwa hasil belajar merupakan pencapaian bentuk perubahan perilaku yang cenderung menetap dari ranah kognitif dan psikomotorik dari proses belajar yang dilakukan dalam waktu tertentu. Hasil belajar merupakan pencapaian bentuk kemampuan yang diperoleh siswa dari ranah kognitif, afektif, dan psikomotorik.

Dalam proses mengajar guru menjadi pemeran utama dalam menciptakan situasi interaktif yang edukatif, yakni interaksi antara guru dengan siswa, siswa dengan siswa dan dengan sumber pembelajaran dalam menunjang tercapainya tujuan belajar. Untuk terwujudnya proses belajar mengajar seperti itu sudah tentu menuntut upaya guru untuk mengaktualisasikan kompetensinya secara profesional, utamanya aspek metodologis. Permasalahan yang dihadapi oleh siswa yaitu kurangnya motivasi dari diri siswa dalam mengikuti proses belajar mengajar beberapa masalah yang terjadi dalam proses belajar mengajar yaitu (1) kurangnya interaksi antara guru dan siswa; (2) penguasaan guru tentang metode pengajaran masih belum maksimal; (3) siswa cenderung pasif dan kurangnya motivasi siswa; (4) metode yang digunakan dalam mengajar belum bervariasi/ monoton; (5) siswa cenderung hanya menghafal bukan memahami materi pelajaran

Tujuan pembelajaran interaktif berbasis aktivitas adalah sebagai berikut (1) meningkatkan partisipasi aktif siswa dalam pembelajaran; (2) meningkatkan pemahaman sosial antara siswa dengan lingkungan sekitar; (3) mendorong siswa untuk dapat menemukan dan menyelidiki sendiri konsep yang dipeljari mudah di ingat dan tidak mudah dilupakan peserta didik; (4) membantu siswa membentuk cara kerja bersama yang efektif, saling membagi informasi, serta mendengar dan menggunakan ide-ide orang lain; dan (5) melatih siswa belajar berpikir analitis dan mencoba memecahkan masalah yang dihadapi sendiri.

Kegiatan pembelajaran interkatif berbasis aktivitas didasarkan pada beberapa prinsip anatara lain (1) somatis yaitu siswa mengalami aktivitas fisik yang memungkinkan siswa berinteraksi dengan orang lain secara berpasangan atau kelompok, dari satu tempat ke tempat lain baik didalam maupun diluar kelas; (2) auditory yaitu siswa dimungkinkan untuk mendengar secara aktif dari bernagai sumber informasi; (3) visual yaitu siswa dimungkinkan untuk melakukan pengamatan gambar atau lingkungan sekitar; (4) intelektual yaitu siswa dimungkinkan untuk melakukan proses tanya jawab terhadap lingkungan belajarnya. 
Prestasi belajar siswa adalah hasil belajar yang dinyatakan dalam bentuk nilai atau dalam bentuk skor, setelah siswa mengikuti pelajaran. Sedangkan, sudjana ( 1990 ) mendefinisikan hasil belajar sebagai kemampuan yang dimiliki siswa, yang ditunjukkan melalui perubahan tingkah laku (behavioral change), setelah ia mengalami pengalaman belajar. Wujud tingkah laku sebagai hasil belajar itu, misalnya dari tidak tahu menjadi tahu, dari tidak mengerti menjadi mengerti, atau dari tidak paham menjadi memahami.

Pembelajaran Ilmu Pengetahuan Alam (IPA) atau science adalah ilmu yang mempelajari tentang peristiwa-peristiwa yang terjadi di alam ini (Iskandar, 1996:2). Menurut Sutrisno (2007:19) secara ringkas dapat dikatakan IPA adalah usaha manusia dalam memahami alam semesta melalui pengamatan yang tepat (correct) pada sasaran, serta penggunaan prosedur yang benar (True), dan dijelaskan dalam penalaran yang sahih (valid) sehingga dihasilkan kesimpulan yang betul (truth). Mata pelajaran IPA berfungsi untuk memberikan pengetahuan tentang lingkungan alam, mengembangkan keterampilan, wawasan dan kesadaran teknologi dalam kaitan dengan pemanfaatannya bagi kehidupan sehari-hari.

Pembelajaran IPA mempelajari peristiwa-peristiwa yang ada di alam dan juga sistem yang terjadi dalam tubuh manusia. Materi berkaitan dengan penghematan energi listrik umumnya bersifat abstrak dan siswa harus mempelajarinya dan dituntut memahami dengan baik dan benar. Pembelajaran ini sangat erat dalam kehidupan sehari-hari, dengan adanya media ini diharapkan siswa dapat mengetahui manfaat dari penghematan energi listrik melalui jenis-jenis lampu, dengan cara mengukur setiap daya listrik dan mengetahui kelebihan dan kekurangan dari masing-masing lampu. Siswa SD sangat menyukai hal-hal yang baru dalam proses pembelajaran, kebanyakan guru menggunakan metode ceramah menyebabkan siswa menjadi bosen dan tidak memahami pelajaran dengan mudah.

Lembar Kerja Peserta Didik (LKPD) merupakan salah satu bahan ajar yang digunakan sebagai panduan untuk melakukan kegiatan penyelidikan atau pemecahan masalah. Dengan adanya LKPD Guided Inquiry ini diharapkan dapat melatih keterampilan proses siswa sehingga dapat menunjang pembelajaran dan dapat digunakan sebagai alternatif media pembelajaran (Trianto, 2008: 148).

Keterlibatan guru dan siswa sangat diperlukan dalam proses pembelajaran adanya anak yang aktif di karenakan ada guru yang kreatif. Guru harus memiliki strategi pembelajaran yaitu dengan menggunakan media sebagai alat pendukung proses pembelajaran, Kata media berasal dari bahasa latin yaitu medius yang artinya tengah, pengantar, menurut Wilkinston media adalah segala alat dan bahan selain buku teks, yang dapat dipakai untuk menyampaikan informasi dalam suatu situasi belajar mengajar. Manfaat media pembelajaran adalah proses pembelajaran menjadi menarik, lebih interaktif, kualitas siswa dapat ditingkatkan, dan proses pembelajaran dapat terjadi di mana saja dan kapan saja.

Penelitian ini pengembangan media pembelajaran yang dapat melibatkan siswa berperan secara aktif dalam melakukan proses pembelajaran dengan baik, dapat mempraktikan dalam kehidupan sehari-hari dan menjaga sumber daya energi listrik dengan baik. Selain itu penelitian ini bertujuan dapat meningkatkan hasil belajar siswa melaui media ini dan siswa menjadi bersikap kritis, kreatif dan berani dalam mempertanggung jawabkan segala sesuatu hasil dari karyanya. Media pembelajaran ini dapat memudahkan siswa dalam memahami materi energi listrik, penelitian ini juga 
membuat bahan ajar untuk meningkat prestasi siswa menggunakan Lembar kerja Peserta Didik (LKPD).

\section{METODOLOGI}

Penelitian yang dilakukan di SD Negeri 105289 Kolam, Alamat Jl. Rukun Desa Kolam Kecamatan Percut Seituan. Subjek dalam penelitian ini adalah siswa kelas VI berjumlah 15 siswa yang terdiri dari 7 siswa laki-laki dan 8 siswa perempuan yang mengikuti mata pelajaran IPA tahun ajaran 2019/2020, waktu penelitian penulis lakukan pada semester ganjil pada tanggal 29 hingga 4 Desember 2019. Jenis Penelitian yang penulis gunakan adalah penelitian dan pengembangan (Research and Development/R\&D), penulis memilih subjek penelitian : (1) validator ( dosen ahli desain dan ahli materi), (2) validator kedua guru SD kelas VI sebagai (ahli desain dan ahli materi 7 ), (3) siswa kelas VI SD Negeri 105289 Kolam, Alamat Jl. Rukun Desa Kolam Kecamatan Percut Seituan, Lembar Kerja Peserta Didik (LKPD) materi penghematan energi listrik. Teknik analisis data yang digunakan dalam melihat kelayakan desain dan materi yang digunakan, dosen memberi penilaian berdasarkan nilai kualitatif kemudian dilakukan pengubahan menjadi Kuantatif sebagai kelayakan terhadap media nyata yang dirancang oleh penulis.

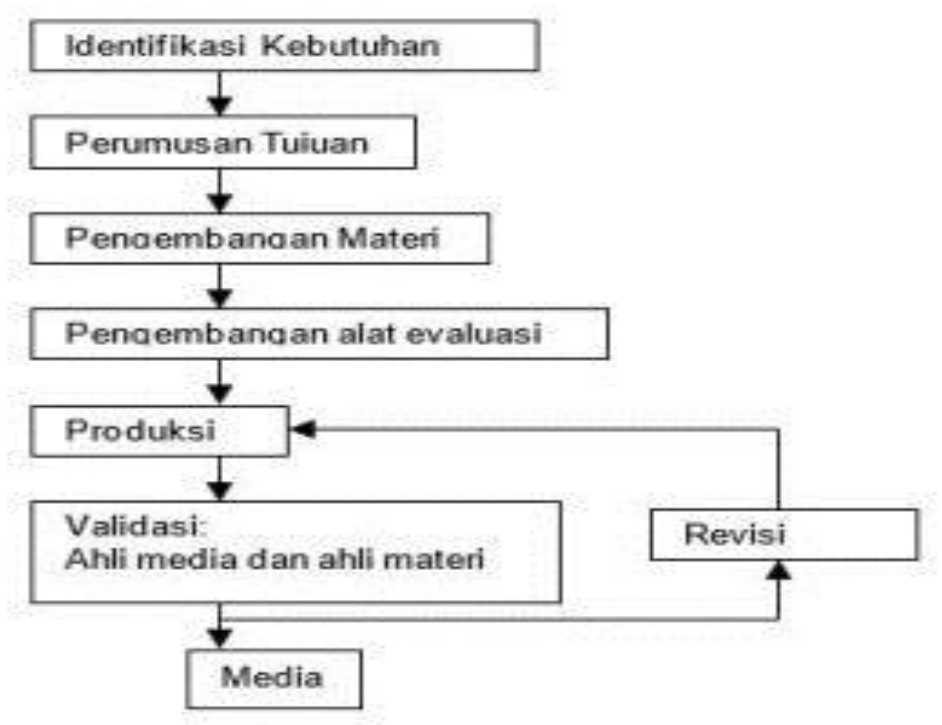

Copyrighte Fatkhon web id

\section{Gambar 1 Pengembangan Media pendidikan}

Penelitian menurut Sadiman, et al (2005: 100-101) urutan dalam mengembangkan program media yaitu: (a) Menganalisis kebutuhan dan karateristik siswa (b) merumuskan tujuan intruksional dengan operasional dank has (c) merumuskan butir-butir materi secara terperinci yang mendukung tercapainya tujuan (d) mengembangkan alat pengukur keberhasilan (e) menulis naskah media (f) mengadakan tes dan revisi. 
Tabel 1. Pengubahan Nilai Kualitatif menjadi Nilai Kuantitatif

\begin{tabular}{lc}
\hline Nilai Kualitatif & Nilai Kuantitatif \\
\hline Sangat Baik & 5 \\
Baik & 4 \\
Cukup baik & 3 \\
Kurang baik & 2 \\
Tidak baik & 1 \\
\hline
\end{tabular}

(Sumber: Djemari, 2008: 123)

Untuk mengukur prestasi siswa peneliti menggunakan proses pengukuran dengan Gain Score, sebagai lotak ukur untuk melihat dan mengetahui keaktifan siswa, mengetahui tingkat pengetahuan siswa dengan hasil dari LKPD yang mereka kerjakan. score dapat dilakukan dengan cara:

$$
\text { Gain Score }=\frac{S_{\text {Postest }}-S_{\text {Postest }}}{S_{\text {maksimum }}-S_{\text {Postest }}}
$$

Tabel 2. Kategori Gain Score Ternomalisasi

\begin{tabular}{cc}
\hline Batasan & Kategori \\
\hline $\mathrm{g} \geq 0,7$ & Tinggi \\
$0,3 \leq \mathrm{g} \leq 0,7$ & Sedang \\
$\mathrm{g} \leq 0,3$ & Rendah
\end{tabular}

(Sumber: Hake 1999:1)

\section{HASIL DAN PEMBAHASAN}

\section{Hasil Penelitian}

Validasi Ahli Materi Penilaian berupa skor dimulai dari 1-5, skor diberikan 13 aspek.yang dibaut oleh peneliti untuk menguji kelayakan materi. Berikut aspek apa saja yang ada didalam validasi ahli materi yang diberi skor. 
Tabel 3 Penilaian Validasi Ahli Materi

\begin{tabular}{|c|c|c|c|c|c|c|}
\hline \multirow{2}{*}{$\begin{array}{l}\text { Aspek } \\
\text { Penilaian }\end{array}$} & \multirow{2}{*}{ Deskription } & \multicolumn{5}{|c|}{ Skala Nilai } \\
\hline & & 1 & 2 & 3 & 4 & 5 \\
\hline \multirow[t]{6}{*}{ Relevansi } & $\begin{array}{l}\text { Materi relevan dengan kompetensi yang harus } \\
\text { dikuasai siswa }\end{array}$ & & & & & $\checkmark$ \\
\hline & $\begin{array}{l}\text { Media penghematan energi listrik relevan } \\
\text { dengan kompetensi yang harus dikuasai }\end{array}$ & & & & & $\checkmark$ \\
\hline & $\begin{array}{l}\text { Kelengkapan materi sesuai dengan tingkat } \\
\text { perkembangan siswa }\end{array}$ & & & & & $\checkmark$ \\
\hline & Materi cukup memenuhi tuntutan kurikulum & & & & $\checkmark$ & \\
\hline & $\begin{array}{l}\text { Ilustrasi media sesuai dengan tingkat } \\
\text { perkembangan siswa }\end{array}$ & & & & $\checkmark$ & \\
\hline & Ilustrasi media yang fungsional cukup & & & & & $\checkmark$ \\
\hline \multirow[t]{4}{*}{ Keakuratan } & $\begin{array}{l}\text { Materi yang disajikan sesuai dengan } \\
\text { kebenaran }\end{array}$ & & & & & $\checkmark$ \\
\hline & $\begin{array}{l}\text { Materi yang disajikan sesuai perkembangan } \\
\text { mutakhir }\end{array}$ & & & & $\checkmark$ & \\
\hline & $\begin{array}{l}\text { Materi yang disajikan sesuai dengan } \\
\text { kehidupan sehari-hari }\end{array}$ & & & & & $\checkmark$ \\
\hline & $\begin{array}{l}\text { Pengemasan materi dalam media sesuai } \\
\text { dengan pendekatan keilmuan yang } \\
\text { bersangkutan (pendekatan saintifik) }\end{array}$ & & & & & $\checkmark$ \\
\hline $\begin{array}{l}\text { Kelengkapan } \\
\text { Sajian }\end{array}$ & $\begin{array}{l}\text { Menyajikan kompetensi yang harus dikuasai } \\
\text { siswa }\end{array}$ & & & & $\checkmark$ & \\
\hline $\begin{array}{l}\text { KonsepDsar } \\
\text { Materi }\end{array}$ & Kesesuaian konsep rangkaian listrik & & & & $\checkmark$ & \\
\hline $\begin{array}{l}\text { Kesesuaian } \\
\text { sajiandengan }\end{array}$ & Mendorong rasa keingintahuan siswa & & & & & $\checkmark$ \\
\hline tuntutan & Mendorong terjadinya interaksi siswa & & & & & $\checkmark$ \\
\hline $\begin{array}{l}\text { Pembelajar- } \\
\text { an yang }\end{array}$ & $\begin{array}{l}\text { Mendorong siswa } \quad \text { membangun } \\
\text { pengetahuannya sendiri }\end{array}$ & & & & & $\checkmark$ \\
\hline $\begin{array}{l}\text { terpusat pada } \\
\text { siswa }\end{array}$ & Mendorong siswa belajar secara berkelompok & & & & & $\checkmark$ \\
\hline
\end{tabular}

Nilai maksimal $13 \times 4=52$

Nilai $=50 / 52 \times 100=96$

\section{Kriteria Kelayakan Secara Deskriptif}

\section{Tabel 4. Kriteria kelayakan secara deskriptif}

\section{Kriteria Validitas}

$81,0 \%-100,0 \%$

$61,0 \%-80,9 \%$

$41,0 \%-60,9 \%$
Tingkat Validitas

Sangat valid, dapat digunakan tanpa revisi

Cukup valid, dapat digunakan namun perlu revisi

Kurang valid, disarankan tidak digunakan karena perlu revisi

besar 
Dari skor yang di nilai oleh validasi ahli media 13 aspek pertanyaan ialah 96 sangat valid, dapat dihasilkan dari penjumlahan 13 jumlah aspek pernyataan, jumlah yang penilaian yang di pilih oleh dosen paling banyak adalah 5 jadi nilai maksimum $13 \times 5=45$ jadi nilai $40 / 45 \times 100=96$, nilai tersebut dapat digunakan tanpa revisi nilai yang diberikan guru IPA SD kelas VI sedangkan Dosen memberikan penilaian sebanyak 76 cukup valid dapat digunakan namun perlu direvisi. Karena dosen lebih banyak memilih nilai 4 jadi nilai maksimum $13 \times 4=52$ kemudian nilai $50 / 52 \times 100=76$

\section{Validasi Ahli Desain}

Ahli Materi memberikan skor yang diberinilai dimulai dari 1-5 dan memiliki 17 aspek pertanyaan sebagai berikut.

\section{Tabel 5. Penilaian media}

\begin{tabular}{|c|c|c|c|c|c|c|}
\hline \multirow{2}{*}{$\begin{array}{l}\text { AspekPenilai } \\
\text { an }\end{array}$} & \multirow{2}{*}{ Deskription } & \multicolumn{5}{|c|}{ SkalaNilai } \\
\hline & & 1 & 2 & 3 & 4 & 5 \\
\hline \multirow{7}{*}{$\begin{array}{l}\text { Tampilan } \\
\text { Umum }\end{array}$} & $\begin{array}{l}\text { Desain media sesuai dengan materi rangkaian } \\
\text { listrik sederhana }\end{array}$ & & & & & $\checkmark$ \\
\hline & Desain media sesuai dengan konsep arus listrik & & & & & $\checkmark$ \\
\hline & $\begin{array}{l}\text { Pengemasan media sesuai integrasi materi } \\
\text { rangkaian listrik sederhana dengan konsep arus } \\
\text { listrik }\end{array}$ & & & & & $\checkmark$ \\
\hline & Desain media menarik dilihat & & & & $\checkmark$ & \\
\hline & $\begin{array}{l}\text { Desain media menyajikan contoh nyata aliran } \\
\text { listrik }\end{array}$ & & & & & $\checkmark$ \\
\hline & $\begin{array}{l}\text { Desain media menyajikan penggunaan listrik dalam } \\
\text { kehidupan sehari-hari }\end{array}$ & & & & & $\checkmark$ \\
\hline & Pemilihan warna dalam media & & & & $\checkmark$ & \\
\hline \multirow{2}{*}{$\begin{array}{l}\text { Tampilan } \\
\text { Khusus }\end{array}$} & Pemilihan media yang unik & & & & $\checkmark$ & \\
\hline & $\begin{array}{l}\text { Membuat integrasi konsep rangkaian listrik } \\
\text { sederhana dan penggunaan listrik dalam kehidupan } \\
\text { sehari-hari. }\end{array}$ & & & & & $\checkmark$ \\
\hline \multirow{4}{*}{$\begin{array}{l}\text { Penyajian } \\
\text { Media }\end{array}$} & $\begin{array}{l}\text { Tampilan media menarik dan mudah dibawa atau } \\
\text { dipindahkan }\end{array}$ & & & & $\checkmark$ & \\
\hline & Diberi judul atau keterangan media & & & & $\checkmark$ & \\
\hline & Terdapat cara penggunaan media & & & & & $\checkmark$ \\
\hline & Penyajian mampu meningkatkan hasil belajarsiswa & & & & & $\checkmark$ \\
\hline
\end{tabular}

\section{Kriteria Kelayakan Secara Deskriptif}

\section{Tabel 6. Kriteria kelayakan secara deskriptif}

Kriteria Validitas

$$
\begin{array}{ll}
81,0 \%-100,0 \% & \text { Sangat valid, dapat digunakan tanpa revisi } \\
61,0 \%-80,9 \% & \text { Cukup valid, dapat digunakan namun perlu revisi } \\
41,0 \%-60,9 \% & \text { Kurang valid, disarankan tidak digunakan karena perlu revisi besar } \\
21,0 \%-40,9 \% & \text { Tidak valid, tidak boleh dipergunakan }
\end{array}
$$


Penelitian ini validasi ahli desain member penelian paling banyak yang dipilih adalah 5 apek pembahasan sebanyak 17 jadi pengitungannya nilai maksimum adalah $17 \times 5=85$ dan nilainya adalah $80 / 85 \times 100=94$ jadi tingkat validitasnya sangat valid dapat digunakan tanpa revisi.

Berikut data siswa yang menjawab soal yang diberikan peneliti, soal tersebut dibagi menjadi 2 soal pretest soal yang diberikan kepada siswa sebelum diajarkan materi tentang penghematan energi listrik, kemudian peneliti member soal posttest sebagai soal untuk mengetahui meningkatnya pengetahuan siswa setelah dijelaskan materi penghematan energi oleh peneliti.

Tabel 7. Hasil soal pretest dan posttest

\begin{tabular}{llll}
\hline NAMA SISWA & PRETEST & POSTEST & N-GAIN \\
\hline AA & 70 & 90 & 0,66 \\
AS & 80 & 90 & 0,5 \\
AW & 60 & 90 & 0,75 \\
DA & 80 & 90 & 0,5 \\
DF & 50 & 90 & 0,8 \\
EV & 70 & 100 & 1 \\
RH & 60 & 90 & 0,75 \\
KS & 40 & 90 & 0,83 \\
OY & 50 & 100 & 1 \\
RF & 80 & 90 & 0,5 \\
RI & 60 & 90 & 0,75 \\
SK & 80 & 100 & 1 \\
TS & 60 & 90 & 0,75 \\
TF & 60 & 80 & 0,5 \\
TPS & 50 & 90 & 0,8 \\
\hline
\end{tabular}

Dari tabel diatas dapat dilihat bahwa sebelum diadakannya materi dan praktik mengenai penghematan listrik melalui media nyata yang diajarkan oleh peneliti peserta didik mendapat nilai dibawah rata-rata ketuntasan yang bernilai 70. Tapi tabel post test memiliki nilai lebih tinggi karena peneliti sudah mengajarkan materi dan praktik media nyata dalam penghematan energi, dapat dilihat nilai yang dicapai siswa lebih tinggi dari pada nilai sebelumnya.

Tabel 8. Persentase Pretest dan Postest

\begin{tabular}{lrcc}
\hline NO & HASIL & PRESTEST & POSTTEST \\
\hline 1. & Nilai Tertinggi & 80 & 100 \\
2. & Nilai Terendah & 40 & 80 \\
3, & Nilai Rata-rata & 63 & 91 \\
\hline
\end{tabular}

Jika rata-rata nilai siswa yang didapat dihitung mengunakan rumus N-Gain, maka dapat dilihat sebagai berikut: 


$$
\begin{aligned}
\mathrm{N}-\text { gain } & =\frac{S_{\text {Postest }}-S_{\text {Postest }}}{S_{\text {maksimum }}-S_{\text {Postest }}} \\
& =\frac{91-43}{100-43} \times 100 \\
& =\frac{48}{57} \times 100 \\
& =84
\end{aligned}
$$

Dari hasil rumus N-Gain secara umum ini dapat dilihat melalui tabel 8 karena angka $\mathrm{N}$-gain mencapai angka 84 maka data tersebut diklasifikasikan yang tinggi, jadi pembelajaran media nyata dapat meningkatkan hasil belajar siswa. Penelitian metode sadiman dapat dikembangkan dengan baik dan benar, metode ini dapat menyelesaikan masalah penghematan energi dengan metode ini tujuan penelitian berjalan dengan baik dan benar.

Peneliti memberikan soal-soal yang ada di LKPD dengan materi pengehematan energi listrik sebanyak 10 soal, soal pada pretest dan posttest dibedakan letak nomor soal dengan pretest. Kemudian peneliti member soal pretest tanpa menjelaskan materi yang akan diajarkan kepada peserta didik, dan soal posttest diberikan setelah peneliti menjelaskan LKPD dan memberikan pengajaran terhadap materi dan media nyata, dan hasil yang didapat peserta didik mengalami peningkatan dalam prestasi belajar setelah peneliti menerangkan materi yang ada di LKPD. Peserta didik di SD Negeri 105289 Kolam, kelas VI berjumlah 20 siswa laki-laki berjumlah 7 peserta didik dan perempuan berjumlah 8 peseta didik.

Peningkatan nilai yang signifikan dari pretest dan posttest disebabkan adanya materi dan alat media nyata dalam pembelajaran penghematan energi, sehingga peserta didik dapat menambah wawasan mengenai energi listrik melalui benda nyata, menambah sikap kritis dalam pembelajaran, dapat mengaplikasikan dalam kehidupan sehari-harinya. Dengan media nyata yang peneliti lakukan kepada peserta didik, peserta didik dapat mengukur daya listrik mengunakan alat Volmeter yang diawasih langsung oleh peneliti. Alat media peneliti mengajarkan proses pembelajaran efektif, dan alat tersebut meransang sistem motorik peserta didik, dan dapat merangsang imajinasi anak dan memberikan kesan terhadap pertumbuhan anak dengan memegang alat tersebut, dan ikut dalam percobaan tersebut sehingga alat panca indra peserta didik merasakannya dengan baik. Media adalah suatu alat untuk menyampaikan informasi atau pesan. Sebagaimana dikemukakan oleh Azhar Arsyad (2013:4) media adalah komponen sumber belajar atau wahana fisik yang mengandung materi intruksional di lingkungan siswa yang dapat merangsang siswa untuk belajar.

Penelitian ini bertujuan untuk meningkatkan prestasi siswa dan meningkatkan hasil belajar siswa dengan menggunakan alat media nyata, dengan begitu dapat dikatakan alat media nyata berhasil meningkatkan hasil belajar peserta didik, keberhasilan peserta didik dipengaruhi oleh 2 jenis faktor antara lain:

Faktor intern adalah faktor yang dialami dan dihayati oleh peserta didik yang berpengaruh pada proses belajar sebagai berikut: (a) Faktor psikologi meliputi intelegensi, perhatian, minat dan bakat (b) faktor kelelahan seperti kelelahan jasmani, dan kelelahan rohani. 
Faktor ekstern adalah faktor yang ada diluar individu. Faktor tersebut adalah faktor sekolah, meliputi metode mengajar, kurikulum relasiguru dengan siswa, disiplin sekolah, alat pelajaran, waktu sekolah, standar pelajaran, keadaan Gedung sekolah, metode mengajar, dan tugas di rumah. (Oktavia, 2015 : 42).

Berdasarkan keseluruhan analisis yang diperoleh dan berdasarkan penelitian maka dapat disimpulkan bahwa media nyata dapat meningkatkan hasil prestasi peserta didik, dan mempengaruhi hasil belajar peserta didik kelas VI SD Negeri 105289. Pada mata pelajaran IPA mengenai materi penghematan energi listrik dengan menggunakan media nyata yang berbasis aktivitas. Tujuan penelitian sudah dapat diselesaikan dengan baik, dan benar dengan menggunakan metode dari Sadiman, dan penghitungan N-Gain.

\section{KESIMPULAN DAN SARAN}

\section{Kesimpulan}

Pembelajaran media nyata dapat meningkatkan prestasi belajar siswa, siswa dapat mengetahui materi tentang penghematan listrik dalam kehidupan sehari-hari dengan baik dan jelas, menggunakan LKPD sebagai panduan dalam melakukan praktikum penelitian .

Dosen dan guru IPA memvalidkan Validasi ahli materi dan Validasi ahli desain yang telah dibuat oleh peneliti sebagai satu kelayakan dalam melakukan penelitian, penelitian tersebut menghasilkan Sangat valid, dapat digunakan tanpa revisi. Peneliti dapat menggunakan media dan materi sebagai suatu bahan untuk diteliti.

\section{Saran}

Sebaiknya peneliti lebih merincikan setiap langkah-langkah siswa dalam melakukan bahan kerja, sehingga siswa tidak merasa kebingungan dan sulit. Selanjutnya, Peneliti juga mengawasi setiap hasil kerja siswa dengan baik, dari mulai siswa mengisi, melihat LKPD, pempraktikan setiap langkah kerja dan hasil dari siswa. Peneliti mengawasi dalam pemakaian benda-benda yang beraliran listrik, bantulah dalam cara pengukuran daya listrik mengunakan voltmeter.

\section{REFERENSI}

Dimyati dan Mudjiono. 2009. Belajar dan Pembelajaran. Jakarta: Rineka Cipta

Elfa Sumiyati, 2017. "penggunaan model pembelajaran interaktif berbasis aktivitas untuk meningkatkan prestasi belajar siswa kelas vi pada pelajaran pkn sd negeri 09 kabawetan”. JPSD Vol. 4 No. 1 (diakses tanggal 14 November 2019)

Islamiar Nur Rani. 2016 "pengembangan lembar kerja peserta didik ipa dengan pendekat Edisian guided inquiry pada materi "tata surya" untuk meningkatkan keterampilan proses siswa" Jurnal Pendidikan Matematika dan Sains. " (diakses tanggal 3 Desember 2019)

M. Shabir U. 2017. kedudukan guru sebagai pendidik: (tugas dan tanggung jawab, hak dan kewajiban, dan kompetensi guru) "VOL. 2 NO. 2 (diakses tanggal 17 November 2019)

Mulyasa. E. Menjadi Guru Profesional, Menciptakan Pembelajaran Kreatif dan Menyenangkan. Cet. VII; Bandung: Remaja Rosda Karya, 2008 
Tustiyana Windiyani, dkk. 2018. " penggunaan media pembelajaran gambar fotografi pada mata pelajaran ilmu pengetahuan sosial siswa sekolah dasar”. JPSD Vol. 4 No. 1. (diakses tanggal 20 November)

Udin, Syaefuddin, dkk. 2008. Perencanaan Pendidikan. Bandung; Remaja Rosdakarya 